\title{
Sensitivity of polar stratospheric cloud formation to changes in water vapour and temperature
}

\section{F. Khosrawi et al.}

Correspondence to: F. Khosrawi (farahnaz.khosrawi@kit.edu)

The copyright of individual parts of the supplement might differ from the CC-BY 3.0 licence. 
Result of the trajectory ensemble statistic for $\mathbf{T}_{\mathrm{NAT}}$ :

Table 1: Total time where the temperature along the back trajectory is below the NAT existence threshold temperature (sum over all 738 back trajectories) for a stratospheric $\mathrm{H}_{2} \mathrm{O}$ mixing ratios of 4.75, 5.0, 5.25, 5.5 and 6.0 ppmv. The calculation was performed assuming an $\mathrm{HNO}_{3}$ mixing ratio of 3, 5 and $7 \mathrm{ppbv}$. Note: The total trajectory ensemble time is $107010 \mathrm{~h}$ $(738$ trajectories $\times 145 \mathrm{~h})$

\begin{tabular}{clccc}
\hline & & $\mathrm{T}$ & $\mathrm{T}-0.5$ & $\mathrm{~T}-1$ \\
\hline $\mathrm{HNO}_{3}$ & $\begin{array}{l}\mathrm{H}_{2} \mathrm{O} \\
(\mathrm{ppbv})\end{array}$ & $\begin{array}{c}\mathrm{T}<\mathrm{T}_{\text {NAT }} \\
(\mathrm{h})\end{array}$ & $\begin{array}{c}\mathrm{T}<\mathrm{T}_{\mathrm{NAT}} \\
(\mathrm{h})\end{array}$ & $\begin{array}{c}\mathrm{T}<\mathrm{T}_{\mathrm{NAT}} \\
(\mathrm{h})\end{array}$ \\
\hline 3 & 4.75 & 32960 & 36776 & 40584 \\
3 & 5 & 34486 & 38301 & 42171 \\
3 & 5.25 & 36024 & 39782 & 43779 \\
3 & 5.5 & 37476 & 41310 & 45210 \\
3 & 5.75 & 38802 & 42709 & 46533 \\
3 & 6 & 40128 & 44080 & 47869 \\
\hline 5 & 4.75 & 38275 & 42133 & 45951 \\
5 & 5 & 39824 & 43810 & 47568 \\
5 & 5.25 & 41430 & 45319 & 49051 \\
5 & 5.5 & 42893 & 46711 & 50560 \\
5 & 5.75 & 44331 & 48126 & 51994 \\
5 & 6 & 45667 & 49460 & 53447 \\
\hline 7 & 4.75 & 41849 & 45746 & 49513 \\
7 & 5 & 43512 & 47312 & 51179 \\
7 & 5.25 & 45062 & 48811 & 52750 \\
7 & 5.5 & 46463 & 50298 & 54262 \\
7 & 5.75 & 47870 & 51735 & 55580 \\
7 & 6 & 49196 & 53180 & 56787 \\
\hline
\end{tabular}


Table 2: Increase in time where the temperature along the back trajectory is below the threshold temperature (sum over all 738 back trajectories) for a stratospheric $\mathrm{H}_{2} \mathrm{O}$ increase of $0.25,0.5,0.75$ and 1.0 ppmv, respectively, and for a stratospheric $\mathrm{H}_{2} \mathrm{O}$ decrease of 0.25 ppmv. The calculation was performed assuming an $\mathrm{HNO}_{3}$ mixing ratio of 3,5 and 7 ppbv.

\begin{tabular}{clccc}
\hline \multicolumn{5}{c}{$\mathrm{T}$} \\
$\mathrm{HNO}$ \\
$\begin{array}{c}\mathrm{HN}_{2} \mathrm{O} \text { increase } \\
(\mathrm{ppbv})\end{array}$ & $\begin{array}{l}\Delta t \text { for } \mathrm{T}<\mathrm{T}_{\mathrm{NAT}} \\
(\mathrm{ppmv})\end{array}$ & $\begin{array}{c}\mathrm{T} \text { for } \mathrm{T}<\mathrm{T}_{\mathrm{NAT}} \\
(\mathrm{h})\end{array}$ & $\begin{array}{c}\Delta t \text { for } \mathrm{T}<\mathrm{T}_{\mathrm{NAT}} \\
(\mathrm{h})\end{array}$ \\
\hline 3 & -0.25 & -1526 & 2290 & 6098 \\
3 & 0.25 & 1538 & 5296 & 9293 \\
3 & 0.5 & 2990 & 6824 & 10727 \\
3 & 0.75 & 4136 & 8223 & 12047 \\
3 & 1.0 & 5642 & 9594 & 13383 \\
\hline 5 & -0.25 & -1459 & 2309 & 6127 \\
5 & 0.25 & 1606 & 5495 & 9227 \\
5 & 0.5 & 3069 & 6887 & 10736 \\
5 & 0.75 & 4507 & 8302 & 12170 \\
5 & 1.0 & 5843 & 9326 & 13623 \\
\hline 7 & -0.25 & -1663 & 2234 & 6001 \\
7 & 0.25 & 1550 & 5299 & 9238 \\
7 & 0.5 & 2951 & 6786 & 10750 \\
7 & 0.75 & 4358 & 8223 & 12068 \\
7 & 1.0 & 5684 & 9668 & 13275 \\
\hline
\end{tabular}




\section{Result of the trajectory ensemble statistic for $\mathbf{T}_{\text {ice }}$ :}

Table 3: Total time where the temperature along the back trajectory is below the ice formation threshold temperature (sum over all 738 back trajectories) for a stratospheric $\mathrm{H}_{2} \mathrm{O}$ increase of 4.75, 5.0, 5.25, 5.5, 5.75 and 6.0 ppmv. Note: The total trajectory ensemble time is $107010 \mathrm{~h}$ (738 trajectories $\times$ $145 \mathrm{~h})$.

\begin{tabular}{lccc}
\hline & $\mathrm{T}$ & $\mathrm{T}-0.5$ & $\mathrm{~T}-1$ \\
\hline $\begin{array}{l}\mathrm{H}_{2} \mathrm{O} \\
(\mathrm{ppmv})\end{array}$ & $\begin{array}{c}\mathrm{T}<\mathrm{T}_{\text {ice }} \\
(\mathrm{h})\end{array}$ & $\begin{array}{c}\mathrm{T}<\mathrm{T}_{\text {ice }} \\
(\mathrm{h})\end{array}$ & $\begin{array}{c}\mathrm{T}<\mathrm{T}_{\text {ice }} \\
(\mathrm{h})\end{array}$ \\
\hline 4.75 & 340 & 771 & 1530 \\
5 & 571 & 1159 & 2152 \\
5.25 & 870 & 1685 & 3030 \\
5.5 & 1240 & 2286 & 4270 \\
5.75 & 1738 & 3133 & 5523 \\
6 & 2299 & 4296 & 6789 \\
\hline
\end{tabular}

Table 4: Increase in time where the temperature along the back trajectory is below the ice formation threshold temperature (sum over all 738 back trajectories) for a stratospheric $\mathrm{H}_{2} \mathrm{O}$ increase of $0.25,0.5,0.75$ and $1.0 \mathrm{ppmv}$, respectively, and for a stratospheric $\mathrm{H}_{2} \mathrm{O}$ decrease of 0.25 ppmv.

\begin{tabular}{lccc}
\hline & $\mathrm{T}$ & $\mathrm{T}-0.5$ & $\mathrm{~T}-1$ \\
\hline $\begin{array}{l}\mathrm{H}_{2} \mathrm{O} \text { increase } \\
(\mathrm{ppmv})\end{array}$ & $\begin{array}{c}\Delta t \text { for } \mathrm{T}<\mathrm{T}_{\text {ice }} \\
(\mathrm{h})\end{array}$ & $\begin{array}{c}\Delta t \text { for } \mathrm{T}<\mathrm{T}_{\text {ice }} \\
(\mathrm{h})\end{array}$ & $\begin{array}{c}\Delta t \text { for } \mathrm{T}<\mathrm{T}_{\text {ice }} \\
(\mathrm{h})\end{array}$ \\
\hline-0.25 & -231 & 200 & 959 \\
0.25 & 299 & 1114 & 2459 \\
0.5 & 669 & 1715 & 3699 \\
0.75 & 1167 & 2562 & 4952 \\
1 & 1728 & 3725 & 6218 \\
\hline
\end{tabular}




\section{Correlation of water vapour and temperature (525-825 K):}

Correlations of temperature and water vapour anomalies were derived for different time scales (all seasons, specific season, single months). The time series are based on data within $70^{\circ}$ and $90^{\circ} \mathrm{N}$ equivalent latitude. A large majority of these calculations indicate an anti-correlation between these two parameters in the altitude range between 475 and $525 \mathrm{~K}$ (see main paper). The correlations are strong in winter and very weak in summer. The figures below show some examples for different data sets for the potential temperature range 525-825 K: (top) T, H2O: Envisat/MIPAS and (bottom) T, H2O: Aura/MLS (Figure 1). The data are averaged over the months January, February and March. The derivation of the anomalies considers the entire time series. The correlation is not as strong as at $475-525 \mathrm{~K}$, but still negative. The weak correlation in the Envisat/MIPAS data is caused by a positive correlation at the begin of the time period considered.
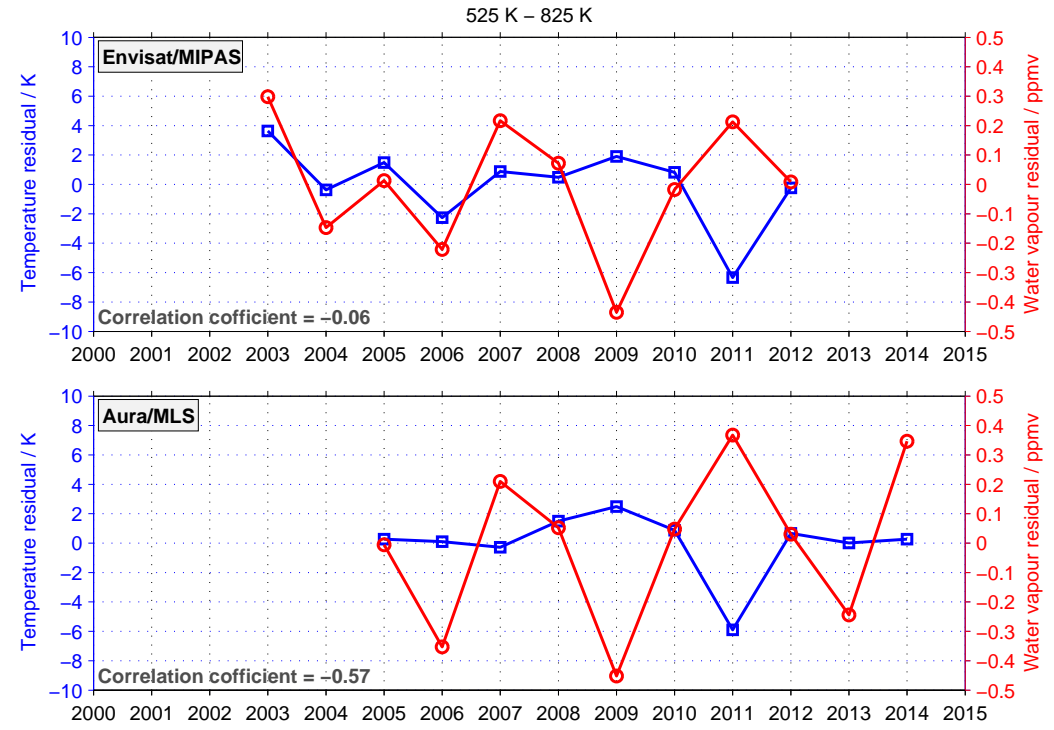

Figure 1: Correlation of temperature (blue) and water vapour (red) anomaly derived from Envisat/MIPAS (top) and Aura/MLS (bottom) for the potential temperature range 525-825 K (3-month average consisting of the months January, February and March; MIPAS: 2002-2012, MLS: 2005-2014). 


\section{Linear trend analyses for Winter (DJF):}

Linear changes in water vapour are investigated by performing seperately a regression analyses of the Envisat/MIPAS (2002-2012) and the Aura/MLS (2004-2014) time series. From these we derive predominantly positive changes in the altitude range between $350 \mathrm{~K}$ to $1000 \mathrm{~K}$ potential temperature. The linear changes from Envisat/MIPAS observations are largely insignificant, while those from Aura/MLS are mostly significant. For the temperature neither of the two instruments indicate any significant changes. Considering the linear trend analyses for solely the winter months (DJF) does not change our results (Figure 2). The resulting areas where the changes are positive and significant within the $2 \sigma$ uncertainty are quite similar to the changes we found when all seasons are considered.
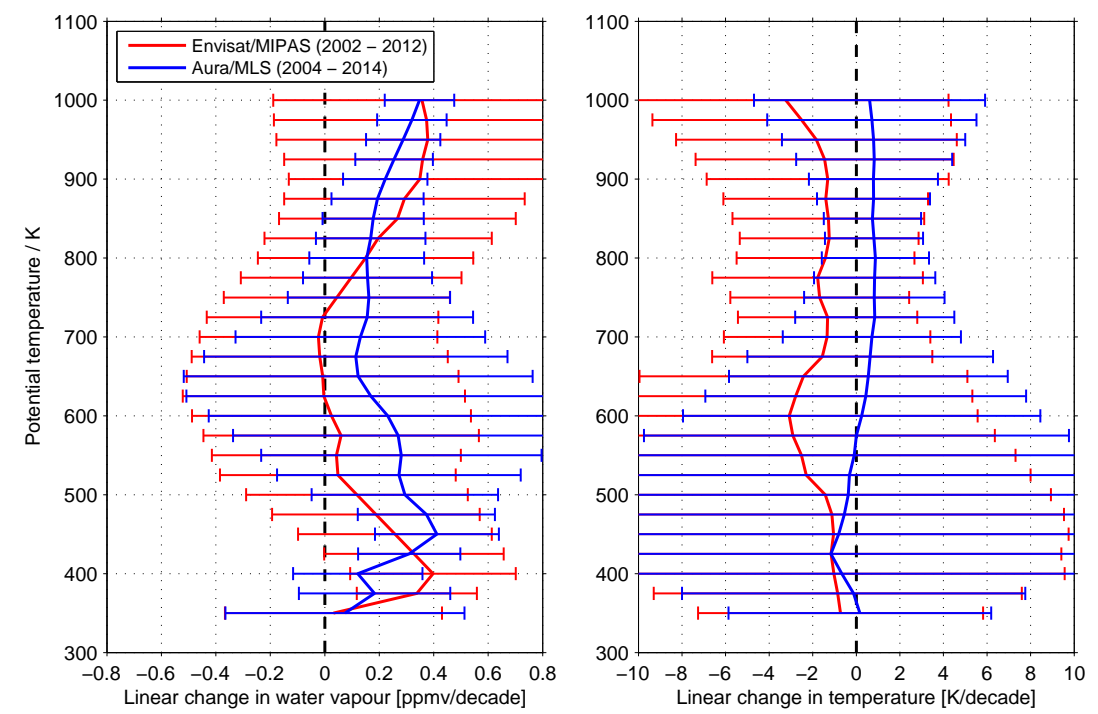

Figure 2: Linear change in water vapour (left) and temperature (right) vs. potential temperature derived from Envisat/MIPAS (2002-2012) and Aura/MLS (2004-2014) for winter (DJF). For the linear change in water vapour derived from Envisat/MIPAS an offset of 0.1 ppmv between the two measurement periods has been considered. As error bars the $2 \sigma$ uncertainty is given. 


\section{Air parcel trajectories:}

Air parcel trajectories were calculated 6-days backward at dates and times when PSCs were measured by CALIPSO during the Arctic winter 2010/2011. The trajectories were calculated at three different altitudes, corresponding to the bottom, middle and top of the cloud. The following figures show the back trajectories for case 1 and case 2 (started on 26 February 2011 00:00 UTC and 23 January 2011 20:00 UTC).

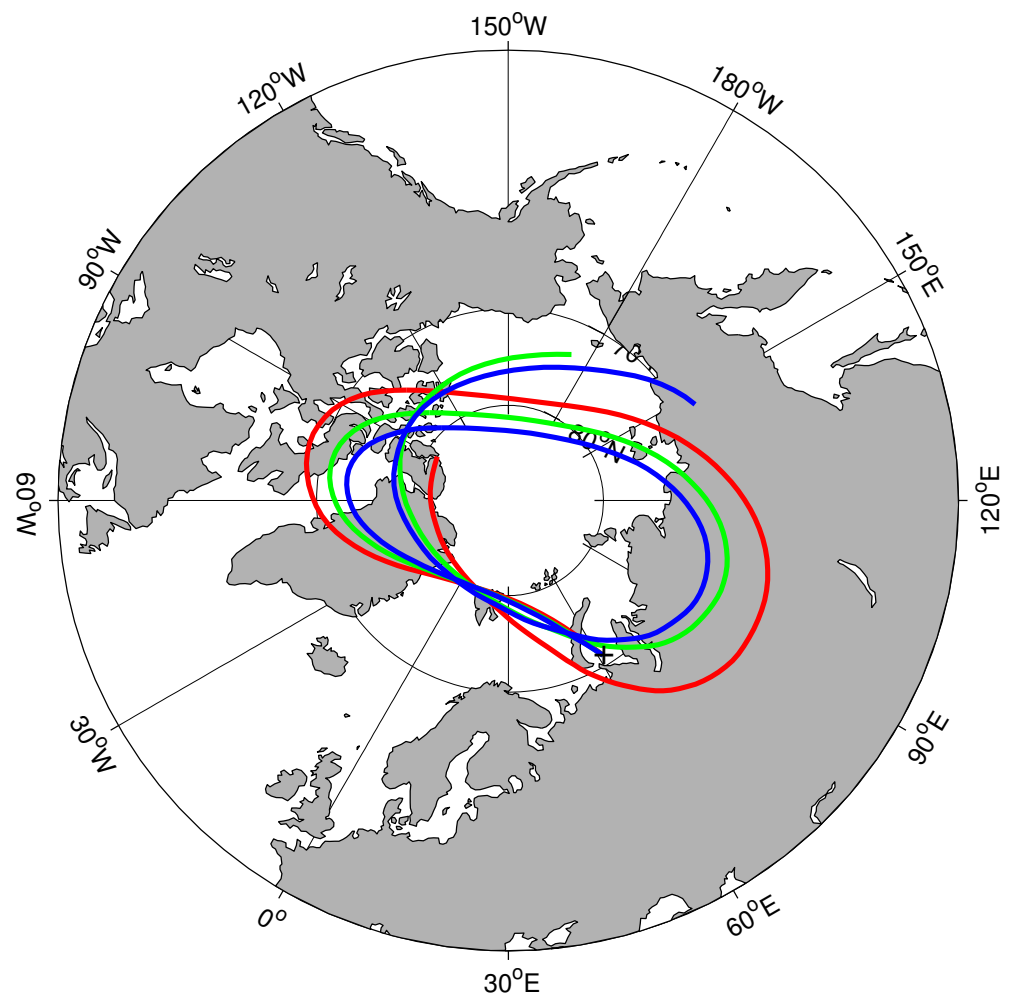

Figure 3: Trajectories calculated 6-days backward with HYSPLIT based on the CALIPSO measurement on 26 February $2011\left(76^{\circ} \mathrm{N}, 61^{\circ} \mathrm{E}\right)$. The trajectories were started at 00:00 UTC at three different altitudes, $20 \mathrm{~km}$ (red), $22 \mathrm{~km}$ (green) and $24 \mathrm{~km}$ (blue). 


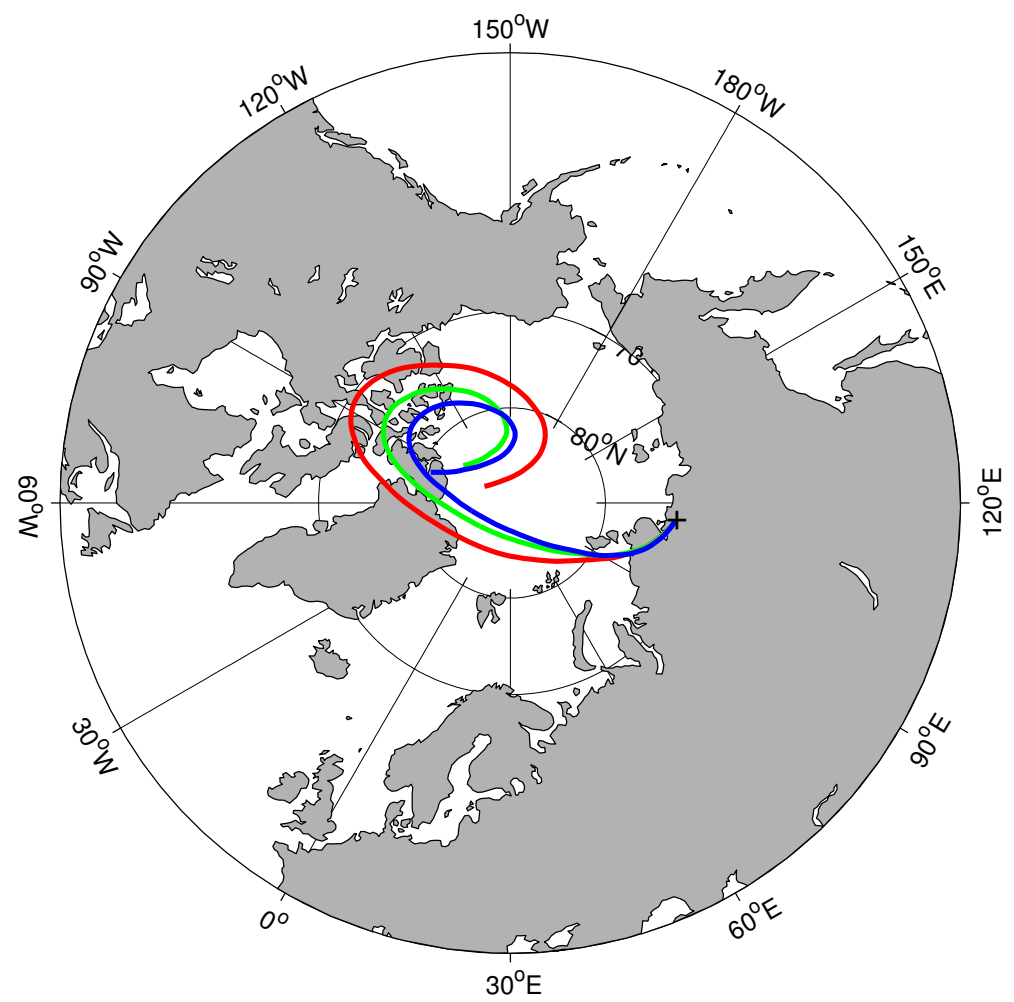

Figure 4: Trajectories calculated 6-days backward with HYSPLIT based on the CALIPSO measurement on 23 Jamuary $2011\left(72^{\circ} \mathrm{N}, 113^{\circ} \mathrm{E}\right)$. The trajectories were started at 20:00 UTC at three different altitudes, $18 \mathrm{~km}$ (red), $20 \mathrm{~km}$ (green) and $22 \mathrm{~km}$ (blue). 